\title{
INDIGENOUS KNOWLEDGE IN THE MANAGEMENT OF A COMMUNITY-BASED FOREST RESERVE IN THE WA WEST DISTRICT OF GHANA
}

\author{
Abdul-Kadiri Yahaya \\ Department of Environment and Resource Studies \\ University for Development Studies \\ Wa, UWR, Ghana \\ Email: cobdouglas2002@yahoo.com \\ doi:10/4314/gjds.v9i1.8
}

\begin{abstract}
Despite the various awareness-creation exercises on community-based management systems by the Forestry Commission and Environmental Protection Agency of Ghana, there appear to be no appreciation of the role of indigenous knowledge in the process. Specifically in the case of the management of the forest reserves, no effective formal strategies exist as yet for working with rural communities to accomplish the goals of nature conservation using local experiences and knowledges. Yet, for the many communities involved in the management of forests and other nature reserves, their local knowledges and experiences have been instrumental in the management of their environments and their resources. This paper evaluates the contributions of indigenous knowledge in community-based management of the natural vegetation by focussing on the case of the Yuoboli Integrated Forest Reserve of the Naaha community in the Wa West District of Ghana. It examines the role of indigenous knowledge in the lives of the people of Naaha and the effectiveness of the strategies used for the management of their natural vegetation. Qualitative and quantitative approaches were used to collect data from primary and secondary sources. The study reveals that conventional approaches are complemented with indigenous knowledge in the management of the Yuoboli Forest Reserve. Also, cherished indigenous methods of managing the reserve are sacrifices, creation of fire belts and taboos such as "no hunting", "no burning" and "no cutting of trees." The study indicates that $81.3 \%$ of the interviewees supports the making of fire belts as one of their respected indigenous ways of managing the reserve and in that respect, 98.4\% affirm that indigenous knowledge supports development. It is recommended that their indigenous knowledge on natural resources management be deepened by the creation of institutions within the community to support the process in order to ensure easy learning and knowledge transfer to subsequent generations. Also, organisations should give support to the community on how to effectively manage the reserve locally. This will encourage participation and empowerment.
\end{abstract}

KEY DESCRIPTORS: Indigenous knowledge, Natural Resources Management, Environmental Degradation, Community-based Approaches, Forest Reserves.

\section{INTRODUCTION}

Indigenous knowledge and natural vegetation management are complementary phenomena essential to human development. Although very little documentation exists on this form of knowledge among communities, it represents an immensely valuable data base that provides humankind with insights on how numerous communities have interacted with their changing environments (Warren, 1992). Considering the increasing trend on the loss of forests and other natural resources, sustainable management systems become important complements to existing forms.

According to Warren (1992), the United States of America has lost about one-third of their forests while Brazil, the Philippines and Europe have lost 40\%, 50\% and 70\% respectively. Despite the great benefit of the forest, $13 \%$ of the world forest land is not under any kind of 
management. Only $2 \%$ of the world's forests are protected. Since the advent of agriculture, about $33 \%$ of the world's forests have been cleared and converted to other uses, mostly farms and human settlement.

In Africa, the natural vegetation is under threat due to expanding agriculture, logging and fuel wood consumption. Around 49\% of the forest cover is Tropical Forests, 15\% are Tropical Rainforests, 5\% are plantations, 24\% are Boreal Forests, 13\% are Temperate Forests and 8\% are Subtropical Forests. The kind of ecological calamity that sent Ethiopia and Sudan's Darfur region from relative food sovereignty to food scarcity may pretty soon fall on Ghana's lot, as deforestation has continued to turn the northern parts of Ghana into wasteland even as it marches violently towards the south.

According to the Forestry Commission of Ghana, about 35\% of the total land mass of the country has already been swallowed by the advancing desert. The three northern regions, Upper East, West and Northern, which together constitute about $40 \%$ of the total land mass of the country are the worst affected areas. It is estimated that the 8.2 million hectares of the closed forest of the country have been depleted leaving a current level estimated at 1.9 to 2.0 million hectares. For instance, in 1998, the total estimated annual loss due to environmental degradation amounted to GH\$41.7 thousand, representing 4 per cent of Gross Domestic Product (GDP) of the country (Forestry Commission of Ghana, 1994).

The Northern Savannah Biodiversity Conservation Project document from the Forestry Department indicate that the forest cover of northern zone constituted about $41,600 \mathrm{~km}$ in 1952 , representing about $46 \%$ of the total land area of the three regions, but the unregulated exploitation of these resources to meet the economic needs of the growing population of the people and livestock have reduced the forest cover of the land to semi-desert and wasteland. A sizeable number of trees are felled every day for the purposes of charcoal burning or firewood and construction works have also aided the speedy advancement of desertification and deforestation in the north.

The effect of desert encroachment in Northern Ghana is alarming. Changes in rainfall patterns and climate in recent times have devastated the lands leaving several kilometres of scorched farmlands, leaner livestock, dried dams, and rivers impoverishing the population. The vegetation of Upper West Region is the Guinea Savannah type, with relatively high density of certain typical tree species. Typical indigenous species such as Dawadawa (parkia biglobosa), Shea (v. paradoxa), Mahogany (khaya senegalensis), Baobab (adansonia digitata) are characteristics of areas of former human settlement. The total area of the Region under permanent forest reserve is about $1107 \mathrm{~km}^{2}$ which constitute about $6 \%$ of the total land area of the region. The region has five to six months of rainfall averaging about $885 \mathrm{~mm}$ and a long period of drought of six to seven months and the mean monthly temperature ranges between $25^{\circ} \mathrm{C}$ to $45^{\circ} \mathrm{C}$. Also, the area is under the influence of the cold, dry and hazy Harmattan from November to February (Soil Research Institute, 2000).

The gradual depletion of the natural vegetation has compelled communities and agencies to seek more effective ways such as community-based systems of checking the degradation and improving the environment. The Yuoboli Forest Reserve is one such. It covers about 150acres in area and has been used to meet the medicinal and nutritional needs of the people of Naaha and surrounding communities. In times past, it served as a place of refuge. Since 1998, the change in the management system has resulted in the renaming of the reserve as the Yuoboli Integrated Community Forest. Some of the plant species in the community are Tukpara [Baobab], Tama [Shea tree], Duo [Dawadawa], Atiye [Cashew], and Kogo [Mahogany].

The idea of forest conservation has been widely propagated due to the loss of certain tree species of economic importance attributable to the changing climate. Over the years, 
communities, non-governmental Organizations and the state have made it their responsibility to preserve the natural vegetation. Some of these areas include the Mole National Park, Esukawkaw Forest Reserve, Kakum National Park and the Yuoboli Integrated Community Forest Reserve. These forest reserves have employed management practices ranging from mainstream scientific to indigenous techniques. Conventional scientific practices such as pruning, weeding and replacement of trees, fertilizer application and the plantation of genetically modified tree species have been adopted in the management of the natural vegetation.

Despite the prospects of the conventional scientific approach, the people of Naaha have employed indigenous management practices to conserve their natural vegetation. Traditionally, the Yuoboli Forest has been managed through indigenous practices such as communal labour, prohibitions and annual libations. Hunting, farming, bush burning, felling of trees and grazing [during farming season] are prohibited. However, dry trees are allowed to be felled and animal grazing is also permitted during dry seasons. Any breach of these rules attracts a penalty of GH\$ 10 , the provision of a 3-year old ram, 2 - fowls and a bottle of local gin.

Regardless of the benefits of the scientific management practices in Naaha, there are shortfalls. The approach does not create any enforceable laws that would deter law breakers and intruders who may temper with the Reserve. It is very complex in terms of its approach and requires training. The training programmes come with cost and the few who are able to understand, use it to the detriment of others. Some of the conventional scientific methodologies come with sophisticated technology which can be expensive and often would lack local content.

The indigenous management practices are sustainable as they are based on local knowledge and experience as such they are easily understandable and acceptable. These indigenous

management practices are participatory as everyone has a role to play in the management of the natural vegetation. Again the indigenous management practices are embedded in the cultural fabric of the people and are easily understood by all. Passing on knowledge and skills to the next generation has been easy. The pouring of libation annually also suggests that the forest has the divine protection of God, community gods and spirits. It is therefore believed that cutting a tree is an offence punishable by the divine master tenders. The extent to which this has been effective is the object of this paper.

\section{LITERATURE REVIEW}

Forests play significant roles in the overall balance of carbon in the atmosphere. Forest carbon sequestration can potentially reduce the accumulation of greenhouse gases in the atmosphere. However, when deforestation takes place, carbon is released into the atmosphere again. Globally, it has been estimated that about $11 \%$ to $39 \%$ of all carbon emissions from human origin come from the forest sector (Hao, et. al. 1990). Regarding global warming, the balance between forest conservation and deforestation can change forest sector activities from a solution to a problem and vice versa.

Vegetation is a given combination of life forms and competing taxa (a group, to which organisms are assigned according to the principles of taxonomy, including species, genus, family, order, class and phylum) with relatively uniform ecological requirements that dominate much of the appearance of the world's landscapes and greatly influences human activities in many areas (Vankat, 1979). The term "natural vegetation" is regarded as vegetation that develops without appreciable interference or modification by humans. Human activities such as ranching, agriculture, forest thinning, and urbanization can cause the land to loss its natural vegetative cover such as grass, shrubs and trees. 
A great deal of the variation seen in climate correlates well with differences in natural vegetation due to the significant influence that climate exerts on vegetation. Ghana's forest area occupies $25 \%$ and anything below is to be regarded as inadequate (Foggie, 2000). At the present level of survival of only $20 \%$ of Ghana's forest, it is obvious that the wave of deforestation is now knocking at the doors of existing forest reserves and exerting maximum pressure on the regulatory processes of forest reserves (Boakye, 1998).

\section{Indigenous Knowledge in Resource Management}

Stiles (1993), defines indigenous knowledge as the systematic body of knowledge acquired by local people through the accumulation of informal experiences and intensive understanding of their environment in a given society. Indigenous knowledge has also been widely applied to remedy situations where technology has failed or been lacking. Indigenous knowledge is an elaborate and multipurpose system integral to society, culture and economy. It is grounded on the idea of the world based on the careful management of local resources. Indigenous knowledge is often the subject of 'scientific study', but does not usually constitute an input into the scientific process, or into decision-making based upon scientific information. Under a technologically driven, fast-changing environment indigenous knowledge may not always catch the attention of decision-makers yet it forms part of discussions in such fora as the Convention on Biological Diversity and the United Nation Convention to Combat Desertification (Hobart, 1993).

From the local environmental point of view, indigenous knowledge and its technologies play primary roles in poverty alleviation. Indigenous knowledge is not proposed because its technologies are less expensive compared to conventional ones, but because it has better results within its local and social context. Sometimes, it has the most refined technologies, other times; it is very simple but still more appropriate, ecologically compatible and locally manageable. Since the 1950s, the rhetoric of development has gone through several stages - from its focus on economic growth, to growth with equity, to basic needs, to sustainable development and to participatory development (Hobart, 1993).

Presently, indigenous knowledge is seen as pivotal in discussions on sustainable resource use and balanced development (Brokensha, 1980). In the 1950s and 1960s, theorists of development saw indigenous knowledge as inefficient, inferior and an obstacle to development. However, in current development discourse, formulations about indigenous knowledge recognize that the derogatory characterization of the knowledge of the poor and marginalized populations may be hasty and naive. In contrast to modernization theorists, advocates of indigenous knowledge underscore the promise it holds for sustainable development (Warren, 1992; Orlove, et. al., 1996). Traditional knowledge is vital for the sustainability of natural resources including forests and water.

According to Pandey (2002a), a discussion on local knowledge is useful for a number of reasons. First, the inadequacy of economic incentives to conserve biodiversity as demonstrated recently by Kleijn and associates (2001) compels the rethinking of the classical utilitarian approach to resource management. Second, an emerging sustainability science (Kates et al., 2001) will need all stocks of knowledge and institutional innovations to navigate transition towards a sustainable planet. Third, the rediscovery of traditional ecological knowledge as adaptive management (Berkes et al., 2000) and need to apply human ecological (Bews, 1935; East, 1936; Muller, 1974) and adaptive strategies for natural resource management (Bates, 2000) offer prospects for scientists to address the problems that beset conservation biologists and restoration ecologists. Fourth, there is an increasing realization that we need innovative ethics and policy to conserve biodiversity and maintain ecosystem functions (Tilman, 2000) and that such ethics need not come from the god; rather, society can cultivate them. Fifth, local knowledge systems are disappearing at a rate that may not allow us to know what value such 
systems had (Cox, 2000; Brodt, 2001; Pandey, 2002a). Finally, in a thought provoking discussion, Cavalcanti (2002) notes that a limitation of economic development is that it is pursued without any considerations - in practice - as to its implications on ecosystems.

Over thousands of years, local people have developed a variety of vegetation management practices that continue to exist in tropical Asia (Pandey, 1998), South America (Atran et al., 1999; Gomez-Pompa and Kaus, 1999), Africa (Getz et al., 1999; Infield, 2001), and other parts of the world (Brosius, 1997; Berkes, 1999). People also follow ethics that often help them regulate interactions with their natural environment (Callicott, 2001). Such systems are often integrated with traditional rainwater harvesting that promotes landscape heterogeneity through augmented growth of trees and other vegetation, which in turn support a variety of fauna (Pandey, 2002a).

In India, these systems have been classified in several ways:

- Religious traditions: temple forests, monastery forests, sanctified and deified trees

- Traditional tribal traditions: sacred forests, sacred groves and sacred trees

- Royal traditions: royal hunting preserves, elephant forests, royal gardens etc.

- Livelihood traditions: forests and groves serving as cultural and social space and source of livelihood products and services (ibid)

Application of local knowledge contributes both to the equity, opportunity, security and empowerment of local communities, as well as, to the sustainability of the natural resources. Local knowledge helps in scenario analysis, data collection, management planning, designing of the adaptive strategies to learn and get feedback and institutional support to put policies in to practice (Getz et al., 1999). Local knowledge has proved useful for forest restoration and protected area management in Rajasthan - one of the driest regions of India with scanty rainfall. Cultural landscapes in rural and urban areas and agro-ecosystems, created by the application of local knowledge, also support a variety of trees, birds and other species, and provide opportunity of integration of nature and society (Taylor, 2002).

A recent seminar organized jointly by the NRI (Natural Resources Institute) of the Britain's Overseas Development Administration (BODA) provided a forum for African farmers to exchange views on ways of reducing crop losses due to pests. The NRI, working on the Mali Millet Project, described how indigenous farmers in north-western Mali placed leaves of the neem tree under the millet heads when they lay them on the ground to dry. This practice discourages insect infestation (Pickstock, 1992).

As cited in Griffiths (2001), the Rio Declaration (Principle 22) outlines the part indigenous people have to play in the drive to sustainable development as follows: "Indigenous people and their communities, and other local communities, have a vital role in environmental management and development because of their knowledge and traditional practices. States should recognize and duly support their identity, culture and interests and enable their effective participation in the achievement of sustainable development." The intergovernmental sustainable development plan of action 'Agenda 21' addresses indigenous communities call for nations to adopt appropriate policies, recognize indigenous values, knowledge and resource management practices, and promotes local participation in sustainable development strategies.

\section{METHODOLOGY}

Apart from the use of documented sources, the study also generated first-hand information from the field. Purposive and simple random sampling techniques were also used to select participants for the study. The study community, Naaha, was randomly chosen out of five communities where indigenous knowledge is used to manage the natural vegetation while a 
combination with purposive sampling has resulted in the participant identification and inclusion in the study. The study relied on qualitative and quantitative approaches for the collection, analysis, presentation and discussion of data. Qualitative methods such as interviews, observation, key informant interviews and focus group discussions were used for data collection. Data was analyzed using SPSS and presented in tables and charts alongside descriptive analyses.

In trying to ensure accuracy and objectivity in terms of the total number of people to be selected for interview, Taro's (1970) formula for sample size computation was used to arrive at a sample size of sixty four.

$$
x=\frac{\mathrm{n}}{1+\mathrm{n}(\mathrm{e})^{2}}
$$

where ' $\mathrm{X}$ ' is defined as the sample size being calculated for, ' $\mathrm{n}$ ' is population of the area and ' $\mathrm{e}$ ' is sample error given a confidence level. Given a confidence level of $87.5 \%$ then the sample error would be $12.5 \%$ thus 0.125 . The total population of Naaha according to the 2000 Population and Housing Census of Ghana was 611 (GSS, 2002).

Hence:

$x=\frac{611}{1+611(0.125)^{2}} \quad \gg \frac{611}{9.5625}=63.8 \quad x=64$

It is believed that, management of the natural vegetation is a responsibility of all, as such, the study was purposively targeted at 34 males and 30 females, who are natives of Naaha. The sample size is male dominant because some indigenous practices such as periodic sacrifices are spearheaded by males. Also, a focus group discussion was held with the forest management committee.

\section{RESULTS AND DISCUSSION}

\section{The Yuoboli Integrated Community Forest}

The Yuoboli Integrated Community Forest reserve was started in 1998 by a citizen of Naaha. It was previously thought to be a place of refuge from their enemies. The changing climate in the northern belt has refined the protective purpose of the reserve. Although various explanations were advanced for starting the reserve, the underlying factor is that of ensuring environmental quality or economic benefits. In the chart below, the reasons for starting the forest reserve are presented. 


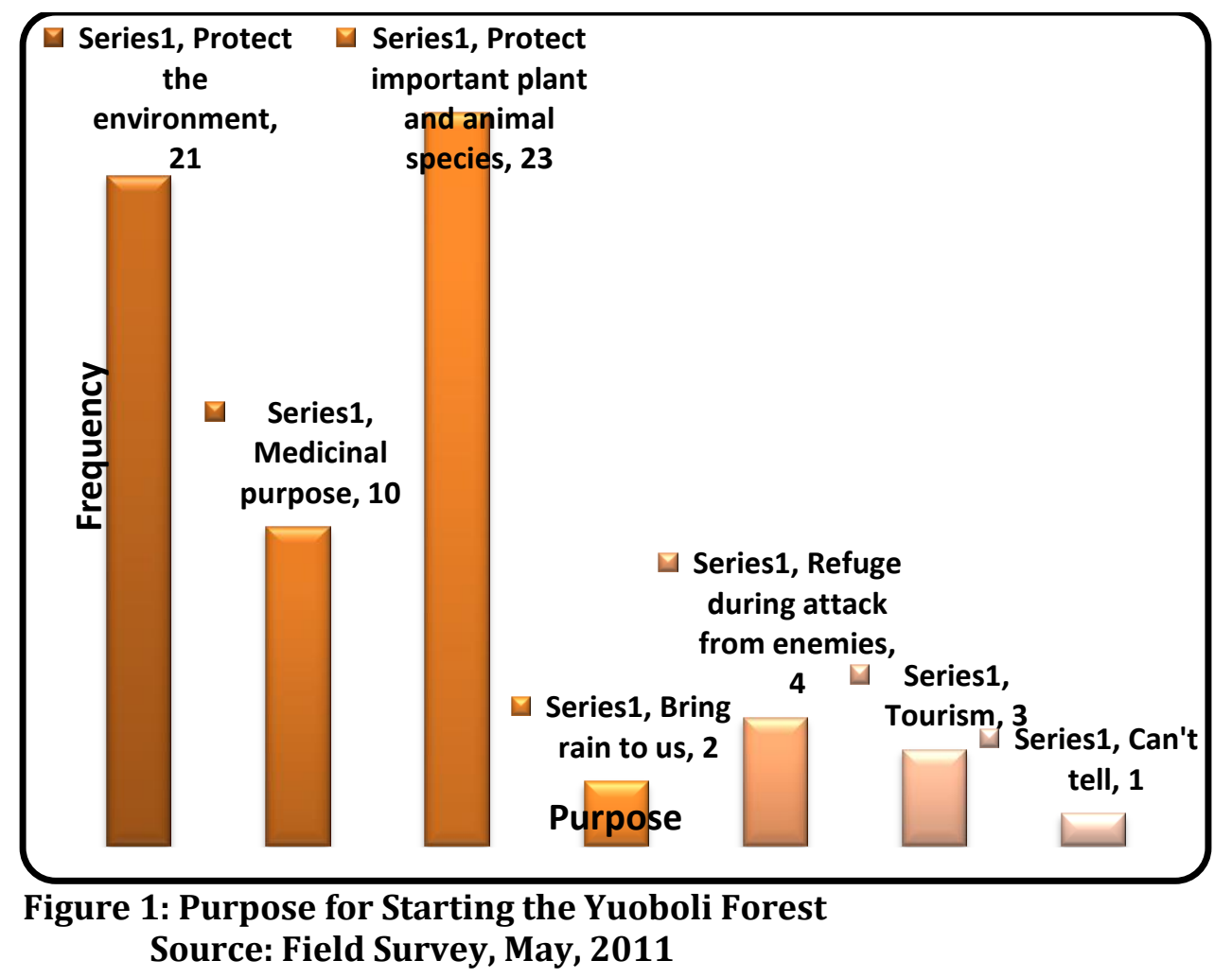

From the field survey, $36 \%$ of respondents indicated that the purpose of starting such a reserve was to protect plant and animal species. Some of them believed that by starting such a project, the forest could grow to serve as an abode for endangered animals. Also, 33\% believe that by starting the community forest, the environment would be protected. Only four percent attach tourism to the development of the reserve.

Despite all these, $6 \%$ of the respondents still hold on to the traditional view of developing the forest. The idea of protection brings to mind the notion of sacred grooves-where the gods live and their protection is heavily felt. Three (3\%) of the respondents believe that the forest will ensure enhanced rainfall pattern.

Several reasons were given by respondents concerning how the forest has served its purpose. These include:

- Protection of significant plant species: $57.7 \%$ of the respondents said that the reserve has helped protect a number of plant species like Dawadawa, Mahogany and Shea.

- Health Purpose: $17.1 \%$ of the respondents testified to medicinal benefits of some of the plant species.

- Economic Purpose: $4.6 \%$ of the respondents agreed that the forest has economic importance such as income from the sale of fuel wood and handicrafts.

- Tourism: The forests attract a good number of nearby community members who visit the forest to learn how it was started and some of the management practices undertaken by the community. This means that the forest has the potential to develop into a tourist site. This represents $8 \%$ of the responses gathered.

However, some of respondents were of the view that the forest has not served its purpose 


\section{Strategies for Managing the Reserve}

The study reveals that conventional approaches are complimented with indigenous knowledge in the management of the Yuoboli Integrated Community Forest reserve. The forest reserve is managed seasonally. It is done mostly during the dry season to allow for the required preparation before the rains draw closer. The indigenous ways are locally designed to suite the local people and are mostly found in their belief systems. From the survey, 22 respondents representing $34.4 \%$ said conventional scientific methods were employed in the management while 35 respondents representing $54.7 \%$ opted for the indigenous practices. To some other people, both management practices are utilized and this represents $10.9 \%$. This is summarized in 3.1

Table 1: Strategies for Managing the Reserve

\begin{tabular}{cl|c|c}
\hline $\begin{array}{l}\text { Manageme } \\
\text { nt practice }\end{array}$ & $\begin{array}{l}\text { Frequenc } \\
\mathbf{y}\end{array}$ & $\begin{array}{l}\text { Percentag } \\
\text { e }\end{array}$ \\
\hline & Conventional & 22 & 34.4 \\
& Indigenous & 35 & 54.7 \\
Both & 7 & 10.9 \\
Total & 64 & 100.0 \\
\hline \hline
\end{tabular}

Source: Field Survey, May, 2011

There is a close competition between the conventional and indigenous practices, as respondents answered the question on the most preferred practice. When asked which one of the above was most ideal, $7.8 \%$ preferred both practices while $1.6 \%$ could not tell which practice was important.

The study further revealed that $54.7 \%$ prefer the indigenous practice while $35.9 \%$ preferred the mainstream scientific practice. Previously in our analysis, $34.4 \%$ said mainstream scientific principles are used in the management of the reserve but on the other hand $35.9 \%$ prefer the mainstream scientific ways which confirms a $1.5 \%$ increase. In simple terms, $1.5 \%$ of the respondents who said both practice are used in the management of the reserve preferred the mainstream scientific practice to the indigenous.

\section{The Import of Indigenous Knowledge}

Indigenous knowledge contrasts with technocratic and bureaucratic scientific procedures. It contributes to even-handed development (Brokensha, 1980). It is less costly and beneficial as no training manuals are required. It is developed from within local sources. Indigenous knowledge is seen to be easier and understandable and would help the forest to grow. Hobart (1993) states that indigenous knowledge has the most refined technologies. Sometimes, it is also very simple but still more appropriate, ecologically compatible and locally manageable. This is based on the fact that indigenous practices on resource management are locally based. The language in which it is communicated also makes it easier and explicable. Figure 2 indicates the benefit of indigenous knowledge to the reserve. 


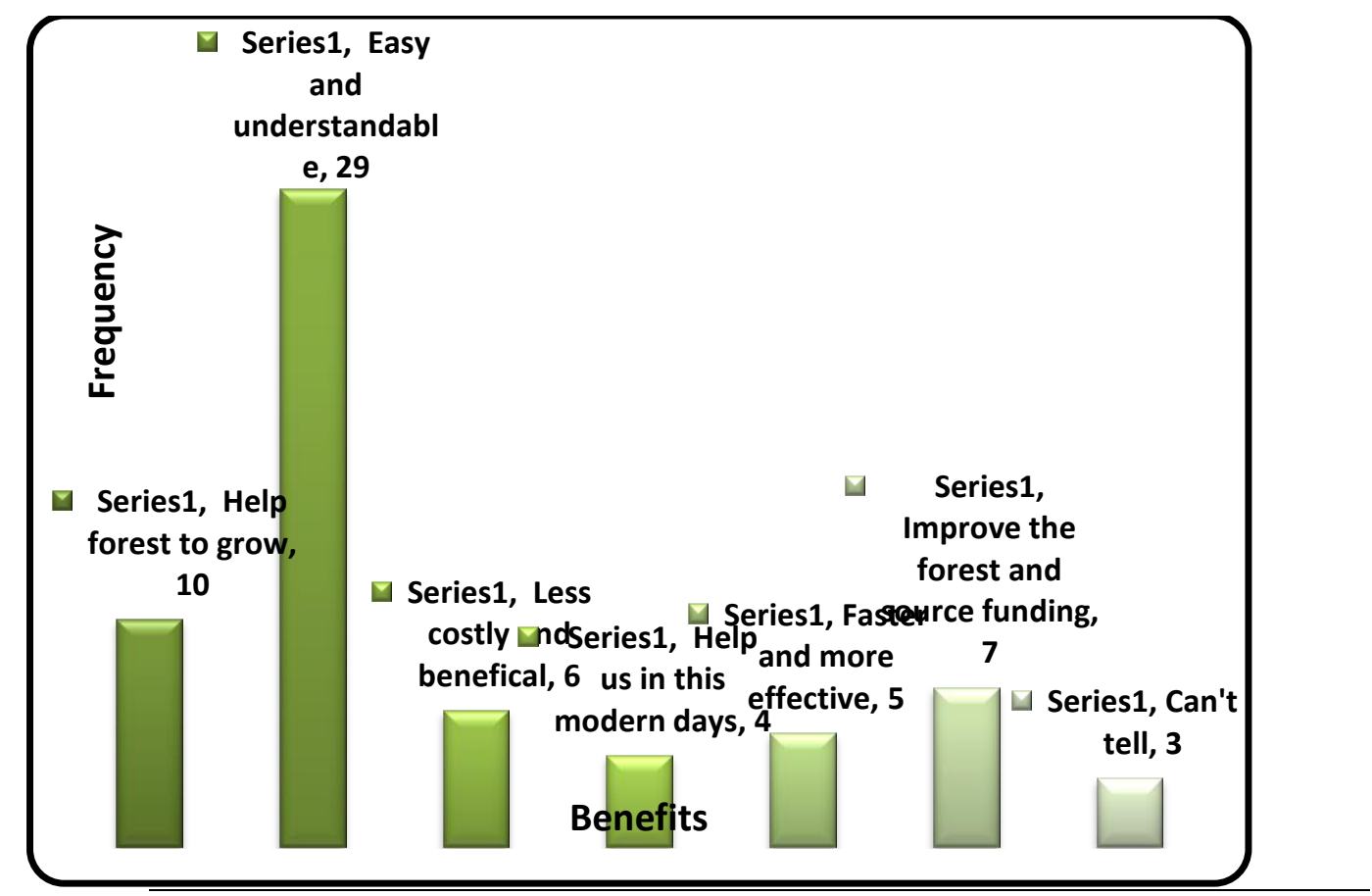

Fig 2: Benefits of IK in Natural Forest Management

Source: Field Survey, May, 2011

From Figure 2 above, it is evident that 29 respondents representing $45.3 \%$ believe that indigenous knowledge is easy and understandable. It has stock in its rich local substance. Also, $15.6 \%$ agree that indigenous practices help the forest to grow while six respondents [9.3\%] were of the view that it was less costly and yet beneficial. A further $11 \%$ of the respondents were of the view that if they were able to use their indigenous knowledge to manage the reserve for it to grow, they could source funding to further sustain the growth. At this point, the management of the forest is seen as the community's shared duty since the forest is for the people. Indigenous practices were said to ensure mutual responsibility and effective results.

\section{Some Indigenous Management Strategies}

A number of indigenous practices were outlined by the respondents. Although respondents always confused the practice with some known conventional scientific principles, there were frequently occurring ones throughout the survey. The community members have blended some indigenous ways and the mainstream scientific principles in the management of the reserve. There were no strict indigenous ways of managing the reserve as in belief systems or taboos. Each response was calculated out of a sample size of sixty four and the rest either mention any one or two of the other responses. The table below summarizes some of the indigenous practices in the management of the forest. 
Table 2: Indigenous Management Practices

\begin{tabular}{l|l|l}
\hline \hline Management Practices & $\begin{array}{l}\text { Responses- } \\
\text { out of 64 } \\
\text { respondents }\end{array}$ & Percentage \\
\hline $\begin{array}{l}\text { No tree cutting in the } \\
\text { forest }\end{array}$ & 37 & 57.8 \\
Making of fire belt & 52 & 81.3 \\
Sacrifices & 17 & 26.6 \\
Replanting of trees & 36 & 56.3 \\
No bush burning in the & 30 & 46.9 \\
forest & 12 & 18.8 \\
No farming in the forest & 9 & 14.1 \\
No hunting in the forest & & \\
\hline
\end{tabular}

Source: Field Survey, May, 2011

From the survey, $81.3 \%$ of the respondents listed fire belt as one of their prominent practice. When questioned about its indigenous basis and whether they were taught, many responded that it was developed from within. To them what constitutes indigenous knowledge is what is developed and learned from within without any external influence. There is no bush burning, farming or hunting in the forest and $46.9 \%, 18.8 \%$ and $14.1 \%$ respectively believe that these principles have sustained the forest over the years. All the practices in Figure 2 are examples of indigenous management practices. One of the indigenous management practices is the replanting of lost trees which constituted $56.3 \%$ of responses.

Although one is not allowed to cut trees, dry trees are felled and replaced. These dry trees have economic importance to the people of Naaha. In our discussion, it was pointed out that the community forest served as a refuge. It is still regarded as a sacred grove and $26.6 \%$ think that sacrifices to the gods have kept the forest budding. These are special traditional beliefs which have been upheld by the community. It is different from the conventional principles because this does not incorporate any theory and practice. These are traditional systems laid down from one generation to other. However, some explain that the existence of religion has actually weakened this reputable principle.

\section{Effectiveness of the Management Practices}

In the previous discussion, some of the strategies and indigenous management practices used by the people of Naaha in their natural vegetation conservation were examined. It is easier to define procedures but always thorny to follow. From the initial analyses, $81.3 \%$ listed making use of fire belts as a thriving practice. In order to ascertain the most preferred, respondents ranked their practices as listed in Table 2. Making of fire belt was the most favored and effective practice. About $42.2 \%$ attested to this fact and described fire belts as the narrow path created about two meters away from the forest to prevent any unforeseen fire outbreak. They are bare grounds which has no grass. These fire belts were made by the community without anyone showing them its purpose and how it is done.

Bush burning is prohibited in the forest reserve. This is also another preferred practice and considered to be very effective. Figure 3 sums up the views of the respondents with regards to the effectiveness of the indigenous practices listed. 


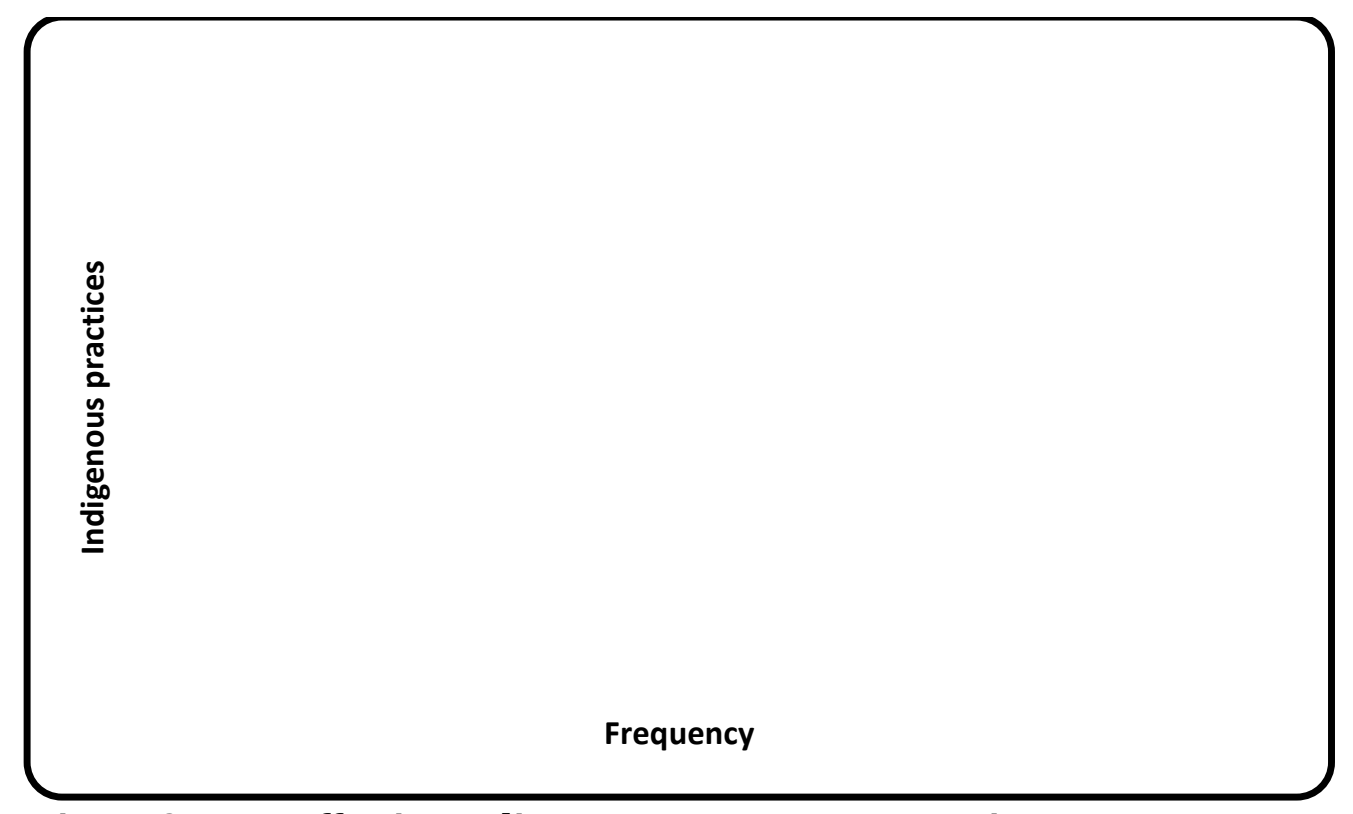

Figure 3: Most Effective Indigenous Management Practices Source: Field Survey, May, 2011

Although Figure 3 above shows the effective practices, there are however various mechanisms in place to ensure that they work. From responses gathered, any breach of these practices would end in a fine in the case of adults and corporal punishment for children. The fines include the payment of GH\$10.00, the provision of a 3-year old ram, 2- fowls and a bottle of local gin. These rules are not documented. One question that respondents failed to answer appropriately had to do with what happens to a person who refuses to abide by these rules. However, in a community where respect for the elderly is supreme, it is easier to carry out such punishment.

The chief and elders are responsible to ensure adherence to the principles. This was agreed upon by 21 respondents representing $45 \%$. In other responses, $48.6 \%$ accept as true that the chief and elders alone cannot effectively ensure this but rather the community as a whole have a role to play to ensure that the indigenous practices are followed. Also, 4.1\% and 1.4\% shared the opinion that forest groups and the Forestry Commission ensure compliance. Figure 4 gives a clearer explanation of respondent's perception about who is supposed to ensure that indigenous practices are followed.

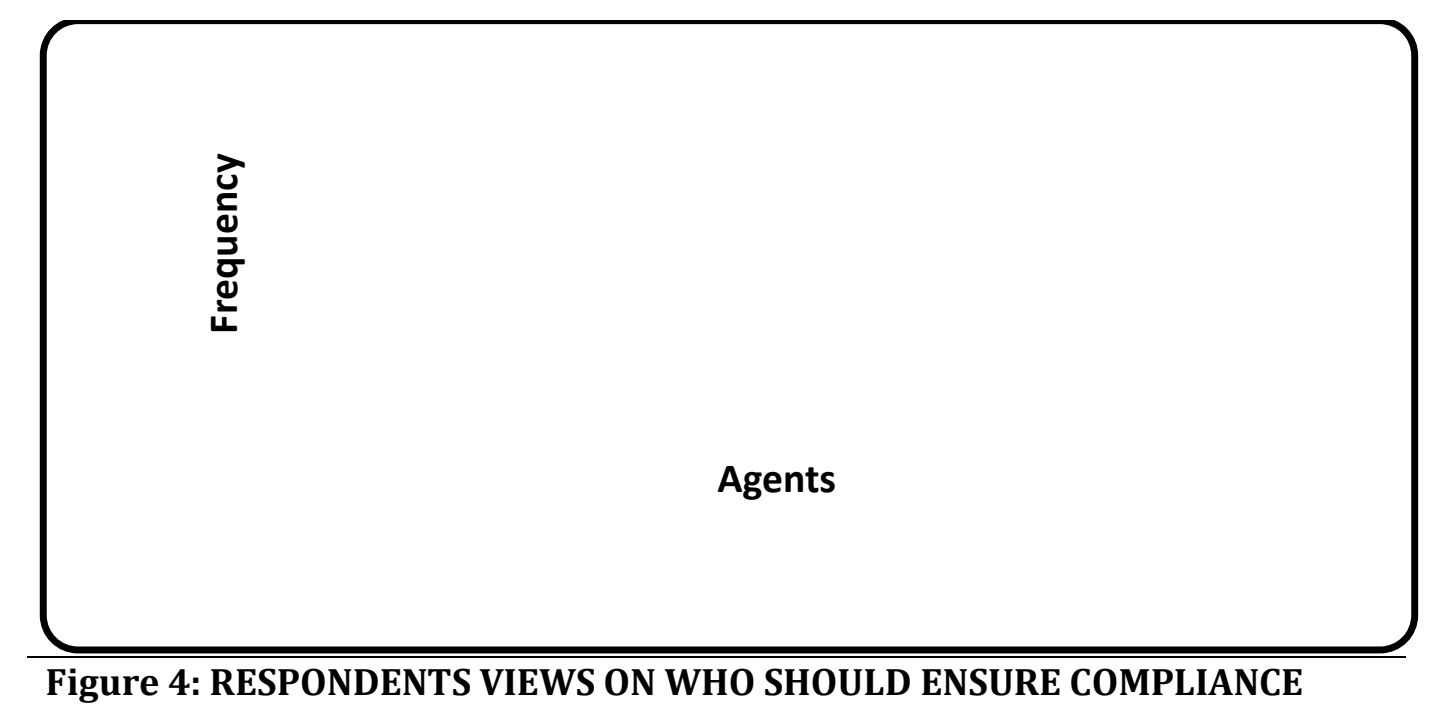

Source: Field Survey, May, 2011 


\section{CONCLUSIONS}

The paper concludes that the people of Naaha have evolved an endogenous mechanism for effectively managing the Yuoboli Forest by combining conventional and indigenous knowledge. It also reveals that, cherished indigenous strategies for managing the reserve are sacrifices, creation of fire belts, and taboos (such as no cutting of trees, no hunting and no bush burning). It also noted that, management of the forest reserve is the responsibility of all, and a breach of any is punishable.

Undoubtedly, the rich experiences of the Naaha community in the management using indigenous knowledge in combination with learned techniques have their merits and weaknesses but they have been effective. These experiences could serve as important lessons for policy formulation and programming initiatives that seek to include community perspectives.

\section{RECOMMENDATIONS}

The following have been recommended to speed up the development of the forest and the community:

- There is the need for local communities in collaboration with the Environmental Protection Agency to deepen indigenous knowledge systems by the strengthening of institutions within the community. This will ensure easy learning and transfer to subsequent generations. These institutions should document and conserve the knowledges and practices to the benefit of all.

- The District Assembly through the Forestry Commission and Environmental Protection Agency should learn from the effective practices of the Naaha community in designing strategies for community-based nature conservation.

- The Regional Tourism Board should collaborate with the community to market the endogenous conservation model so that benefits inuring from it can go into support the community in its development efforts.

- In addition to the penal and compliance system adopted, the community could also provide more education for young people on the values and principles while making benefits and oversight more inclusive.

\section{REFERENCES}

Atran, C.; Sullivan, P. and Martin, A. (1999). Indigenous Knowledge Systems in Contemporary

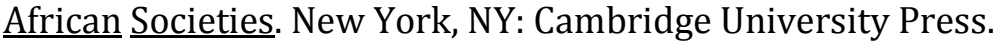

Berkes, F. (1999). Sacred Ecology: Traditional Ecological Knowledge and Resource Management. Philadelphia, PA: Taylor and Francis.

Bews, J.W. (1935). Human Ecology. Oxford University Press, London, pp. 312.

Boakye, Amoako-Atta (1998). Preservation of Sacred Groves in Ghana: Esukawkaw Forest Reserve and its Anweam Sacred Grove. South-South Co-operation Programme on Environmentally Sound Socio-Economic Development in the Humid Tropics. (Working paper № 26), UNESCO.

Brodt, J. (2001). Human Ecology. London, UK: Oxford University Press. 
Brokensha, D. (1980). Indigenous Knowledge Systems and Development. Lanham, USA: University Press of America.

Brosius, P. J. (1997). Endangered forest, endangered people: environmentalist representations of indigenous knowledge. Human Ecology 25: 47-69.

Callicott, J. B. (2001). Multicultural environmental ethics. Daedalus 130(4): 77-98.

Cavalcanti, C. (2002). Economic thinking, traditional ecological knowledge and ethnoeconomics. Current Sociology 50: 39-55.

Cox, P. A. (2000). Will tribal knowledge survive the millennium? Science 287: 44-45.

East, E. M. (1936). Human ecology. Science 83: 305-306.

FAO (2005b). State of the world's forests. Rome, Italy: United Nations Food and Agriculture Organization (FAO).

Forgie, M. (2000). Ghana's Forest and Management Practices. Environmental Management Bulletin, Volume 1: 79-117

Forestry Commission of Ghana (1994). Forest and Wildlife Policy. Accra: Forestry Commission of Ghana.

Ghana Statistical Service (2002). 2000 Population and Housing Census of Ghana. Accra, GH: Ghana Statistical Service

Getz, W.M.; Fortmann, L.; Cumming, D.; Toit, J. du; Hilty, J.; Martin, R.; Murphree, M.; OwenSmith, N.; Starfield, A.M. and Westphal, M.I. (1999). Sustaining natural and human capital: villagers and scientists. Science 283: 1855-1856.

Gomez-Pompa, A. and Kaus, A. (1999). From pre-Hispanic to future conservation alternatives: lessons from Mexico. (Proceedings of the National Academy of Sciences) USA 96: 5982-5986. Grifith, A. (2001). The Politics of Traditional Knowledge Systems: The African Perspective. Singapore Environmental Bulletin, No. 13: 153-192

Hao, W. M.; Smith,M.H. and Cruten, P. J. (1990). 'Estimates of Annual Regional Release of CO2 and other trace Gases to the Atmosphere from fires in the Tropics.' In Goldammer, J.G (ed.). Fire in the Tropical Biota. (440 - 462) Berlin, Germany: Springer- Verlag.

Infield, M. (2001). Cultural values: a forgotten strategy for building community support for protected areas in Africa. Conservation Biology 15: 800-801.

Hobart, M. (1993). An Anthropological Critique of Development: The Growth of Ignorance. London, UK: Routledge.

Kates, R. W.; Michael, P. A, and Andrian F (2001). Sustainability Science. Science 292: 641-642. Kleijn, D.; Berendse, F.; Smit, R. and Gillissen, N. (2001). Agri-environment schemes do not effectively protect biodiversity in Dutch agricultural landscapes. Nature 413: 723-725.

MNRT (2008a). Participatory Forest Management in Tanzania. Facts and Figures. Forestry and Beekeeping Division of Tanzania. 
Muller, C.H. (1974). Human Ecology. Science, 183: 368-412.

Pandey, D. N. (2002a). Traditional Knowledge Systems for Biodiversity Conservation. Organization of the United Nations (FAO) Forestry Paper. FAO, Rome, Italy. Pp.22-41

Pickstock, M. (1992). Small Farmer Knowledge and Pest Control. International Agricultural Development, 12(1): 5-7.

Soil Research Institute (2000). Soil, Vegetation and Climatic Characteristics of Sub-Saharan Africa. Volume 2.pp 74-124

Stevenson, G. (1996). The cultures of Environmentalism: Asian Experience. London, Routledge.

Stiles, T. (1993). The politics of Natural Resource Management in Natural Resource Management. Toronto: Earthscan,

Taylor, P.D. (2002). Fragmentation and cultural landscapes: Tightening the relationship between human beings and the environment. Landscape and Urban Planning 58: 93-99.

Tilman, D. (2000). Causes, consequences and ethics of biodiversity. Nature 405: 208-211.

United Nations Environment Programme (UNEP) (2002). Africa Environment Outlook. Past, present and future perspectives, Nairobi: Kenya: UNEP.

Vankat, S. (1979). Challenges of Managing the Natural Vegetation. New York: Earthscan.

Warren, D.M. (1992). Indigenous knowledge, bio-diversity conservation and development. Keynote address. International Conference on Conservation of Biodiversity in Africa, Kenya. 